\title{
Girdin interaction with vimentin induces EMT and promotes the growth and metastasis of pancreatic ductal adenocarcinoma
}

\author{
WULIN WANG $^{1 *}$, HAO CHEN $^{1,2^{*}}$, WENJIE GAO $^{1 *}$, SHENG WANG $^{3}$, KAI WU $^{4}$, \\ CHEN LU ${ }^{1}$, XIAGANG LUO ${ }^{1}$, LIANHONG LI ${ }^{1}$ and CHUNZHAO YU ${ }^{1}$ \\ ${ }^{1}$ Department of General Surgery, Second Affiliated Hospital, Nanjing Medical University, Nanjing, Jiangsu 210000; \\ ${ }^{2}$ Department of Gastrointestinal Surgery, Jingzhou Central Hospital, Second Clinical Medical College, Yangtze University, \\ Jingzhou, Hubei 434000; ${ }^{3}$ Department of Hepatobiliary and Pancreatic Surgery, The Affiliated Suqian Hospital of \\ Xuzhou Medical University, Suqian, Jiangsu 223800; ${ }^{4}$ Department of Gastrointestinal Surgery, \\ Second Affiliated Hospital of Changzhou, Nanjing Medical University, Changzhou, Jiangsu 213000, P.R. China
}

Received January 7, 2020; Accepted March 26, 2020

DOI: $10.3892 / o r .2020 .7615$

\begin{abstract}
Pancreatic ductal adenocarcinoma (PDAC) is a highly malignant cancer of the digestive tract that has a high potential for metastasis and a poor prognosis. Girdin was first reported in 2005 as an actin-binding protein and was designated as Akt-phosphorylation enhancer (APE); thus, Girdin has been revealed to have an important role in regulating cancer development. There is additional evidence indicating that Girdin is associated with cell proliferation, migration, invasion and survival in certain cancers. However, the potential mechanisms involving Girdin and mobility in pancreatic cancer have not been elucidated. In the present study, it was revealed that Girdin was highly expressed in pancreatic cancer tissue and was associated with tumor grade. The present study, to the best of our knowledge, is the first aimed at investigating the unknown role of Girdin in PDAC metastasis. A short hairpin RNA for Girdin
\end{abstract}

Correspondence to: Professor Chunzhao Yu, Department of General Surgery, Second Affiliated Hospital, Nanjing Medical University, 121 Jiangjiayuan, Gulou, Nanjing, Jiangsu 210000, P.R. China

E-mail: chunzhaoyu@hotmail.com

${ }^{*}$ Contributed equally

Abbreviations: EMT, epithelial-mesenchymal transition; TGF- $\beta$, transforming growth factor- $\beta$; BSA, bovine serum albumin; p-AKT, phosphorylated protein kinase B; AKT, protein kinase B, SDS-PAGE, sulphate-polyacrylamide gel electrophoresis; PBS, phosphate-buffered saline; TBST, Tris-buffered solution containing Tween; PVDF, polyvinylidene fluoride; MMP2/9, matrix metalloproteinase-2/9; p-PI3K, phosphorylated phosphatidylinositol 3-kinase; PI3K, phosphatidylinositol 3-kinase; PDAC, pancreatic ductal adenocarcinoma

Key words: Girdin, growth, metastasis, pancreatic ductal adenocarcinoma, EMT
(sh-Girdin) was successfully constructed with recombinant adenoviral vectors to suppress the expression of Girdin in pancreatic cancer cell lines (PANC-1 and BXPC-3). The silencing efficiency of the Girdin shRNA was determined by RT-qPCR and western blot analysis, and decreased Girdin expression in the cytoplasm was revealed by immunofluorescence detection. Then, sulforhodamine B (SRB) and colony formation assays were used to confirm that the knockdown of Girdin inhibited proliferation in vitro, and Transwell assays were used to examine the influence of Girdin knockdown on cellular mobility. Animal experiments also confirmed that silencing the expression of Girdin in pancreatic cancer cells inhibited the growth and metastasis of pancreatic cancer in vivo. Transforming growth factor- $\beta$ (TGF- $\beta$ ) is a common inducer of epithelial-mesenchymal transition (EMT) and can effectively induce EMT in PDAC. Notably, TGF- $\beta$-treated cells exhibited changes in the classic biological markers of EMT. The expression of E-cadherin, a marker of the epithelial phenotype, increased, and the expression of $\mathrm{N}$-cadherin and vimentin, markers of the interstitial phenotype, decreased in response to sh-Girdin. According to these experiments, Girdin may affect pancreatic cancer progression and development by interacting with vimentin. Therefore, there is evidence indicating that Girdin could be designated as a prognostic biological indicator and a candidate therapeutic target for pancreatic cancer.

\section{Introduction}

Pancreatic cancer remains the fourth most common cause of cancer-associated deaths of the digestive system and the fourth leading cause of cancer-related deaths in America (1). It was reported that 18.1 million new cancer cases and 9.6 million cancer-related deaths occurred in 2018. PDAC has been revealed to account for approximately $2.5 \%$ of new cancer cases and $4.5 \%$ of cancer-related deaths in 185 countries (2). Moreover, the mortality of pancreatic cancer was revealed to be nearly $94.1 \%$, and the 5-year relative survival rate less than $10 \%$, which is the lowest rate among digestive system malignancies (2-4). Pancreatic cancer was reported as the seventh 
leading cause of cancer-related deaths in patients regardless of sex worldwide in 2018 and may become the second leading cause of cancer-related deaths in America by $2030(2,5)$. PDAC has a poor prognosis owing to several factors, including inefficient diagnosis due to the absence of evident early pathognomonic symptoms and propensity to develop drug resistance (6-7). In the advanced stages, local infiltration or distant metastasis are observed among most PDAC patients. Tumor metastasis renders treatment strategies such as surgery and chemotherapy rarely effective (8-10). However, the underlying mechanisms governing PDAC carcinogenesis and metastasis remain largely unclear. Therefore, there is an urgent need to identify both novel early biomarkers for diagnosing and sufficiently effective therapeutic targets to improve the prognosis of pancreatic cancer.

Epithelial-mesenchymal transition (EMT) is a gradual developmental process in which epithelial cells undergo various biochemical changes; during this process, epithelial cells gradually lose the epithelial phenotype and acquire mesenchymal features $(11,12)$. Evidence suggests that the invasion and dissemination of cancer cells are due to the transformation of epithelial cells (13). Transforming growth factor- $\beta$ (TGF- $\beta$ ) is a crucial driver of EMT and usually promotes the process of EMT (14). TGF- $\beta$ has also been demonstrated to have an essential role in the regulation of cell invasion and EMT progression in pancreatic cancers (15-16). The poor prognosis of pancreatic cancer is closely related to its early metastasis, and EMT is a critical event in the process of cancer metastasis. Thus, it is important to understand the potential role of TGF- $\beta$ and Girdin in the process of EMT in PDAC.

Girdin, also known as Akt phosphorylation enhancer, Hook-related protein 1 and G-interacting vesicle-associated protein, is a novel actin protein containing 1870 amino acids in humans with a molecular mass of $220-250 \mathrm{kDa}$; it was independently reported by four groups in 2005 (17-20). Considering its role in regulating intracellular microfilaments and actin organization and cell motility, it is referred to as GIRDers of actIN filament (21). Recently, Girdin was revealed to be aberrantly expressed in a variety of malignancies, such as glioma, lung cancer, breast cancer, esophageal squamous cell carcinoma and colon cancer (22-26). There is evidence suggesting that Girdin plays a key role in promoting carcinogenesis and development in lung tumors, regulating invasion and metastasis in breast cancer and glioma cancer and leading to poor prognosis of cancer patients $(23,24,27)$. Moreover, Girdin was also revealed to be involved in angiogenesis and autophagy via its regulation of signaling pathways (28-29). Previous research by our group revealed that Girdin was highly expressed in PDAC and was closely related to the pathological grade of PDAC patients (30). These studies indicated that Girdin may be a promising biomarker for some cancer patients and an important participant in the carcinogenesis and progression of cancer. However, the underlying mechanisms of Girdin in the metastasis and TGF- $\beta$-induced EMT of PDAC have not been well demonstrated.

In the present study, it was revealed that Girdin was highly expressed in PDAC cells and that high Girdin expression was related to poor prognosis in PDAC patient data from GEPIA. Inhibiting the expression of Girdin inhibited the proliferation, migration and invasion of pancreatic cancer cells in vitro. In addition, knockdown of Girdin suppressed PDAC growth and metastasis in vivo. The molecular mechanism assays indicated that Girdin may promote the invasion and migration of pancreatic cancer cells via the PI3K/AKT signaling pathway. Mechanistic investigations also elucidated that Girdin may interact with vimentin to suppress TGF- $\beta$-induced EMT in pancreatic cancer.

\section{Materials and methods}

Cell culture. Human pancreatic nestin-expressing (hTERT-HPNE) cells were separated from human pancreatic cells and used as normal human pancreatic ductal cells. The three human PDAC cell lines (AsPC-1, PANC-1 and BxPC-3) and the normal human pancreatic ductal cell line (HPNE) were purchased from the American Type Culture Collection (ATCC). The human PDAC cell lines PANC-1 and BxPC-3 and the control HPNE cells were cultured in Dulbecco's modified Eagle's medium (DMEM) (Gibco; Thermo Fisher Scientific, Inc.). The medium contained $4.5 \mathrm{~g} / 1 \mathrm{D}$-glucose, and $10 \%$ fetal bovine serum (FBS) (Wisent, Inc.) was added. AsPC-1 cells were maintained in RPMI-1640 medium (Gibco; Thermo Fisher Scientific, Inc.) with 10\% FBS. The cells aforementioned were all cultured in a sterile cell culture incubator, which contained $5 \% \mathrm{CO}_{2}$ and maintained in a humidified environment at $37^{\circ} \mathrm{C}$.

Cell infection and TGF- $\beta$ treatment. Recombinant adenoviruses were constructed containing a specific short hairpin RNA of Girdin (sh-Girdin) or a nontargeting short hairpin RNA designed as the control (sh-NC). The vector containing pAd-U6-CMV-GFP was used for synthesizing recombinant adenoviruses. After the recombinant adenovirus was amplified and purified from 293A cells, it was used to transfect the experimental cells. Untreated cells were also used as the normal group $(\mathrm{N})$ and compared with the experimental control. When the cells grew to $70-80 \%$ confluence, recombinant adenovirus was added to the six-well plate with serum-free medium for 4-6 h. After the cells were washed twice with PBS, the cells were cultured for 24 or $48 \mathrm{~h}$ in medium with or without serum for the experiments. Western blot analysis and q-PCR analysis were used to confirm the infection efficiency. The TGF- $\beta$ treatment time was $24 \mathrm{~h}$, and the concentration was $10 \mu \mathrm{M}$; the cells were co-incubated with TGF- $\beta$ and sh-NC or sh-Girdin.

Cell proliferation assay. The cells of various treatment groups (N, sh-NC and sh-Girdin) were adjusted to a density of $5 \times 10^{4}$ cells/1, and then a $100-\mu 1$ volume of the suspension $\left(5 \times 10^{3}\right.$ cells) was added to a 96 -well plate. After the virus effectively transfected the cells, the cells were replated, and the cell viability was detected by sulforhodamine B (SRB) (Shanghai Sixin Biological Technology Co., Ltd.) analysis at four different time-points of incubation (24, 48, 72, and $96 \mathrm{~h}$ ).

Subsequently, a 96-well culture plate was removed at the corresponding time and fixed with $1 \%$ trichloroacetic acid (TCA) (Sinopharm Chemical Reagent Co., Ltd.). The plate was left in a refrigerator at $4^{\circ} \mathrm{C}$ overnight or at room temperature for $3 \mathrm{~h}$ and then washed 5 times with PBS. When the 96-well plate was dry, it was stained with $100 \mu 1 \mathrm{SRB}$ solution $(0.4 \% \mathrm{w} / \mathrm{v})$ for another $15 \mathrm{~min}$ in a place protected from light at room 
temperature. Then, $1 \%$ glacial acetic acid was utilized to wash the wells 5 times, and the plate was dried overnight under a fume hood. The protein-bound SRB stain was solubilized by adding $100 \mu \mathrm{l}$ Tris-base $(10 \mathrm{mM}, \mathrm{pH}=10.5)$ (Sinopharm Chemical Reagent Co., Ltd.) into every well. Ultimately, the cell proliferation rate was detected by a spectrophotometer that measured the absorbance at $490 \mathrm{~nm}$.

Colony formation assay. The sh-RNA-transfected or untreated cells were cultured for $24 \mathrm{~h}$, and 300 cells were seeded in 6 -well plates. Cells were cultured for two weeks, and when colonies were clearly visible, $4 \%$ paraformaldehyde was used to fix the cells overnight at $4^{\circ} \mathrm{C}$; the wells were washed two times with PBS and stained with $0.4 \%$ crystal violet staining solution for $15 \mathrm{~min}$ at room temperature. Colony formation was quantified by counting with the naked eye. The number of colonies is presented in the figures.

Transwell migration and invasion assay. PANC-1 and BxPC-3 cells in a $60 \times 15 \mathrm{~mm}$ cell culture dish were treated with or without recombinant adenovirus for $6 \mathrm{~h}$ and then stimulated with or without LY294002 (10 $\mu \mathrm{M} / \mathrm{ml})$ (Cell Signaling Technology, Inc.) for $24 \mathrm{~h}$. Cell migration was assessed by Transwell assay, and the various groups (N, sh-NC, sh-Girdin, sh-NC+DMSO, sh-NC+LY294002, sh-Girdin+DMSO, sh-Girdin+LY294002) of cells $\left(1 \times 10^{4} /\right.$ well $)$ were seeded into the upper chamber of a Transwell ( $8 \mu \mathrm{m}$ PET, Millicell; EMD Millipore) with $200 \mu \mathrm{l}$ serum-free DMEM. For the invasion assay, Matrigel (BD Biosciences) mixed with serum-free DMEM (1:5) was added to the 24-Well Hanging Inserts of the upper chamber, and the volume of the mixed liquid was $60 \mu \mathrm{l}$. Then, the chambers were placed in the incubator for $8 \mathrm{~h}$ at $37^{\circ} \mathrm{C}$. A volume of $800 \mu \mathrm{l}$ DMEM supplemented with $10 \%$ FBS (Wisent, Inc.) was added to the lower chambers before adding cells to the upper chamber. Thereafter, the cells added into the chambers were placed in a sterile incubator to invade for $24 \mathrm{~h}$. The migrated/invaded cells were fixed with $800 \mu \mathrm{l} 4 \%$ paraformaldehyde in a $4^{\circ} \mathrm{C}$ freezer overnight and stained with $0.4 \%$ crystal violet staining solution for $15 \mathrm{~min}$ at room temperature. The cells on the top of the membranes were removed with swabs, and then the remaining cells were washed twice with PBS. The migrated/invaded cells were imaged and counted in five separate fields under a light microscope (Olympus Corporation; magnification, $\mathrm{x} 10$ ), and the experiment was performed at least 3 times.

RNA isolation and real-time quantitative PCR (RT-qPCR). TRIzol ${ }^{\circledR}$ reagent (Tiangen Biotech Co., Ltd.) was used to extract the total RNA from the PDAC cell lines, and according to the manufacturer's operating instructions, the PrimeScript ${ }^{\mathrm{TM}}$ RT reagent kit (Takara Bio, Inc.) was used to reverse-transcribe it into cDNA. The mRNA levels of Girdin were normalized to those of $\beta$-actin and examined by the following primers: Girdin forward, 5'-AGGAAATGGGACCAACCTTGA-3' and reverse, 5'-GTGCATTCTAAGTGAGGCATCAT-3'; $\beta$-actin forward, 5'-ATCGTGCGTGACATTAAGGAGAAC-3' and reverse, 5'-AGGAAGGAAGGCTGGAAGAGTG-3'. Girdin mRNA was amplified by RT-qPCR. SYBR Green and the iQ5 Multicolor Real Time Detector System (both from Bio-Rad Laboratories, Inc.) were used according to the manufacturer's protocol. The thermocycling conditions were as follows: Reverse transcription at $50^{\circ} \mathrm{C}$ for $2 \mathrm{~min}$, denaturation at $95^{\circ} \mathrm{C}$ for $10 \mathrm{~min}$, followed by 40 cycles of amplification (15 sec at $95^{\circ} \mathrm{C}, 1 \mathrm{~min}$ at $60^{\circ} \mathrm{C}$ and $1 \mathrm{~min}$ at $72^{\circ} \mathrm{C}$ ). Relative levels of mRNA expression were obtained with the $2^{-\Delta \Delta} \mathrm{Cq}$ method (31).

Western blot analysis. PDAC cells were washed with PBS and then lysed with phenylmethanesulfonyl fluoride (PMSF) and RIPA lysate buffer at a ratio of 1:100 (Thermo Fisher Scientific, Inc.). The bicinchoninic acid assay was applied to examine the protein concentration in the various groups. Equal amounts of protein $(30 \mu \mathrm{g})$ were separated by sodium dodecyl sulfate polyacrylamide gel electrophoresis (SDS-PAGE) at $6 \%$ or $8 \%$ concentrations. Polyvinylidene fluoride (PVDF) $(0.22-\mu \mathrm{m}$ diameter) (EMD Millipore) membranes were used to transfer the protein for 1.5 or $3 \mathrm{~h}$ at 95 volts. Then, the membranes were blocked with a total volume of $25 \mathrm{ml}$ dry skimmed milk $(5 \%, \mathrm{w} / \mathrm{v})$ or bovine serum albumin $(5 \%, \mathrm{w} / \mathrm{v})$, which was dissolved in Tris-buffered saline (TBS) containing $0.05 \%$ Tween-20 (TBST) for $2 \mathrm{~h}$ at room temperature. Before placing them on a horizontal shaker in a four-degree refrigerator overnight, the membranes were incubated with the following primary antibodies: Anti-Akt (1:1,000; product code ab32505), anti-PI3k (1:1,000; product code ab133595), anti-Girdin (1:1,000; product code ab179481) were purchased from Abcam; anti-p-AKT (1:500; cat. no. AF0016), anti-p-PI3K (1:500; cat. no. AF3241) were obtained from Affinity Biosciences.; anti-MMP2 (1:1,000; cat. no. 10373-2-AP), anti-MMP9 (1:1,000; cat. no. 10375-2-AP), anti-E-cadherin (1:1,000; cat. no. 20874-1-AP), anti-N-cadherin (1:1,000; cat. no. 22018-1-AP), anti-vimentin (1:1,000; cat. no. 60330-1-Ig) and anti-HRP-conjugated beta-actin mouse $\mathrm{McAb}$ (HRP-60008) were acquired from ProteinTech Group, Inc. TBST buffer was used to wash the membrane three times for $30 \mathrm{~min}$, and then the membranes were incubated with the respective homologous horseradish peroxidase-conjugated secondary antibodies: goat anti-mouse $\operatorname{IgG}(\mathrm{H}+\mathrm{L})(1: 8,000$; cat. no. 33201ES60) was purchased from Shanghai Yesheng Biotechnology Co., Ltd. and goat anti-rabbit IgG-HRP antibodies $(1: 8,000 ;$ sc2004) were acquired from Santa Cruz Biotechnology, Inc. The blots were incubated at room temperature on a low-speed centrifuge shaker for $2 \mathrm{~h}$. The blots were washed three times with TBST for $45 \mathrm{~min}$ and Western Bright $^{\mathrm{TM}}$ ECL (cat. no. R-03031-D25), which was purchased from Advansta, Inc., was applied following the manufacturer's protocol. The blots were observed and imaged through by Chemiluminescence Gel Imager (Tanon-5200Multi; Shanghai Tanon Technology Co., Ltd.).

Immunofluorescence. Before adding sterile confocal glass slides (BD Biosciences) to 24-well plates, a small amount of serum-free DMEM was added to enhance the adsorption capacity of the slides. PANC-1 or BxPC-3 cells were seeded into 24-well plates and cultured for $24 \mathrm{~h}$. Then, the cells were fixed with $4 \%$ paraformaldehyde on glass slides overnight at $4^{\circ} \mathrm{C}$. After washing with PBS, the cells were permeabilized with $0.1 \%$ Triton $\mathrm{X}-100$ for $15 \mathrm{~min}$ and then washed three times for $15 \mathrm{~min}$. Next, $3 \%$ bovine serum albumin was used to block the cells for $30 \mathrm{~min}$ at $37^{\circ} \mathrm{C}$. Then, the primary antibody, anti-Girdin (1:200; product code ab179481) or anti-vimentin 
(1:200; cat. no. 60330-1-Ig), was added to the glass slides overnight; next, the cells were washed with PBS 3 times for 15 min. The cells were then incubated with fluorescent secondary antibodies Alexa Fluor ${ }^{\circledR} 594$ donkey anti-rabbit $\operatorname{IgG}(\mathrm{H}+\mathrm{L})$ (1:1,000; product code ab150076) and Alexa Fluor ${ }^{\circledR} 488$ goat anti-mouse IgG $(\mathrm{H}+\mathrm{L})(1: 1,000$; product code ab150113; both from Abcam) for $\sim 30 \mathrm{~min}$ at $37^{\circ} \mathrm{C}$. Finally, DAPI (blue) was used to counterstain cell nuclei for $1 \mathrm{~min}$ at room temperature, and the cells were examined by fluorescence microscopy (Olympus Corporation) at a magnification of x100.

Co-immunoprecipitation. The Girdin immunocomplex was isolated by coimmunoprecipitation (Co-IP). PANC-1 and BxPC-3 cells were lysed in Nonidet P-40 buffer $(0.5 \%$ Nonidet P-40, 0.25\% deoxycholate, $50 \mathrm{mM}$ Tris- $\mathrm{HCl}(\mathrm{pH} 8.0), 5 \mathrm{mM}$ EDTA and $150 \mathrm{mM} \mathrm{NaCl})$. Total cell lysates $(1,000 \mathrm{ml})$ containing a protein weight of $1,000 \mu \mathrm{g}$ were incubated with 3-5 $\mu \mathrm{g}$ of specific antibodies (anti-Girdin or anti-vimentin) overnight at $4^{\circ} \mathrm{C}$. Protein $\mathrm{G}$ beads (EMD Millipore) were washed three times with Nonidet P-40 buffer before incubation with the cell lysate. One milligram of precleared lysate was incubated with $200 \mu \mathrm{l}$ of Protein G beads, which were washed with $1 \mathrm{ml}$ of lysis buffer three times and cross-linked with the indicated antibody. The beads were added to the lysate and incubated for $\sim 6 \mathrm{~h}$ at $4^{\circ} \mathrm{C}$. Then, the beads were extensively washed with $1 \mathrm{ml}$ of lysis buffer three times and $1 \mathrm{ml}$ of PBS one time. SDS-PAGE $2 \mathrm{X}$ loading buffer $(50 \mu \mathrm{l})$ was applied to obtain the proteins from the beads. The immunoprecipitated protein complexes resolved by $6 \%$ SDS-PAGE were analyzed by western blotting.

In vivo tumor formation and metastasis assays. The animal experiments strictly complied with the Guidelines for the Care and Use of Laboratory Animals of the National Institutes of Health [Eighth Edition (2011)]. The protocol of this experiment was approved by the Animal Ethics and Welfare Committee (AEWC) of Nanjing Medical University (IACUC-1601161). A total of 20 six-week-old BALB/c male mice were purchased from the Animal Center of Nanjing University (Nanjing, China). The mice were reared under certain pathogen-free conditions of laboratory animals, and housed (temperature: $25^{\circ} \mathrm{C}$ and humidity: 55\%) in microisolator individually ventilated cages with ad libitum water and food. One cage for every five mice. Every three days, the health of the mice was observed, and water, food, and litter were changed. BxPC-3 cells were stably transfected with recombinant adenovirus that contained sh-Girdin or empty vector. Then, the cells were washed and harvested with PBS. Cells were resuspended in PBS at $5 \times 10^{7}$ cells $/ \mathrm{ml}$. After the mice were anesthetized by chloral hydrate $(400 \mathrm{mg} / \mathrm{kg}$ of body weight) through intraperitoneal injection, then the cells $\left(1 \times 10^{7}\right.$ cells, $\left.0.2 \mathrm{ml} \mathrm{PBS}\right)$ were injected into the right side of the ventral anterior of 10 athymic male nude mice. After six days, the tumor size of mice was calculated and then calculated again every 3 days; tumor volumes were calculated with the formula: $\mathrm{V}=0.5 \mathrm{xDxd}^{2}$ (V, volume; D, longitudinal diameter; and d, latitudinal diameter). The mice were euthanized by injecting a concentration of $100 \%$ carbon dioxide into a sealed box at a flow rate of $20 \%$ per min for $5 \mathrm{~min}$. The death of mice was confirmed by observing the absence of breathing and a heartbeat, or dilated pupils. The size and weight of tumors in all mice were also determined and analyzed.

Exploring the role of Girdin in tumor metastasis in vivo. Transfected PDAC cells ( $5 \times 10^{6}$ cells, $0.1 \mathrm{ml}$ PBS) were injected into nude mice through the tail vein when the 10 mice were anesthetized. After the tail vein injection, the health status and diet of the nude mice were regularly observed. At six weeks, one of the mice in the sh-Girdin group exhibited weight loss and diet reduction. The experiment was terminated and the 10 nude mice were euthanized with carbon dioxide as aforementioned. Subsequently, the lungs of nude mice in sh-NC group and sh-Girdin group were surgically dissected. Half of the tumor samples and the lung metastasis nodules were fixed for immunohistochemical staining, and the other half was stored at $-80^{\circ} \mathrm{C}$ for protein detection.

Immunohistochemical staining. The tumor samples and the lung metastasis nodules were fixed in $4 \%$ paraformaldehyde for $\sim 2$ days at room temperature and embedded in paraffin. The thickness of the sections was $\sim 5 \mu \mathrm{m}$. Tissue sections were stained with hematoxylin staining solution for $5 \mathrm{~min}$ and stained with $1 \%$ eosin for $2 \mathrm{~min}$ at room temperature for hematoxylin and eosin (H\&E) staining. The sections of tumor samples were incubated with the anti-Ki67 antibody (1:200; product code ab92742) or anti-Girdin (1:200; product code ab179481; both from Abcam) at $4^{\circ} \mathrm{C}$ overnight and a goat anti-rabbit IgG-HRP antibodies (1:1,000; sc2004) at room temperature for $30 \mathrm{~min}$. Then, a DAB Substrate Kit (Maxin) was used for the following immunohistochemical staining according to the manufacturer's instructions. The staining results were observed and imaged through light microscopy (Olympus Corporation) at a magnification of $\mathrm{x} 4$ and $\mathrm{x} 40$.

Statistical analysis. GraphPad Prism 8.0 software (GraphPad Software, Inc.) was used for statistical analyses Data were statistically analyzed using Student's t-test for comparisons of two groups and ANOVA followed by Dunnett's post hoc test for comparisons of more than two groups. Kaplan-Meier plotter was used to analyze the prognostic role of Girdin in pancreatic cancer in GEPIA data (http://gepia.cancer-pku.cn/). Log-rank tests were performed for the survival time probability of PDAC patients with high and low expression of Girdin expression. The experiment results were independently reproduced three times, and the experimental data are presented as the means $\pm \mathrm{SD}$. A two-sided P-value $<0.05$ was considered to indicate a statistically significant difference.

\section{Results}

Expression levels of Girdin in PDAC cell lines and Girdin protein are associated with poor survival. To explore the expression level of Girdin in PDAC, the mRNA level of Girdin was analyzed by RT-qPCR. Western blotting was used to investigate the protein expression of Girdin in three PDAC cell lines (PANC-1, AsPC-1 and BxPC-3) and a normal human pancreatic ductal cell line (hTERT-HPNE). The results demonstrated that the level of Girdin was significantly enhanced in PDAC cell lines compared to hTERT-HPNE (Fig. 1A-C). PANC-1 

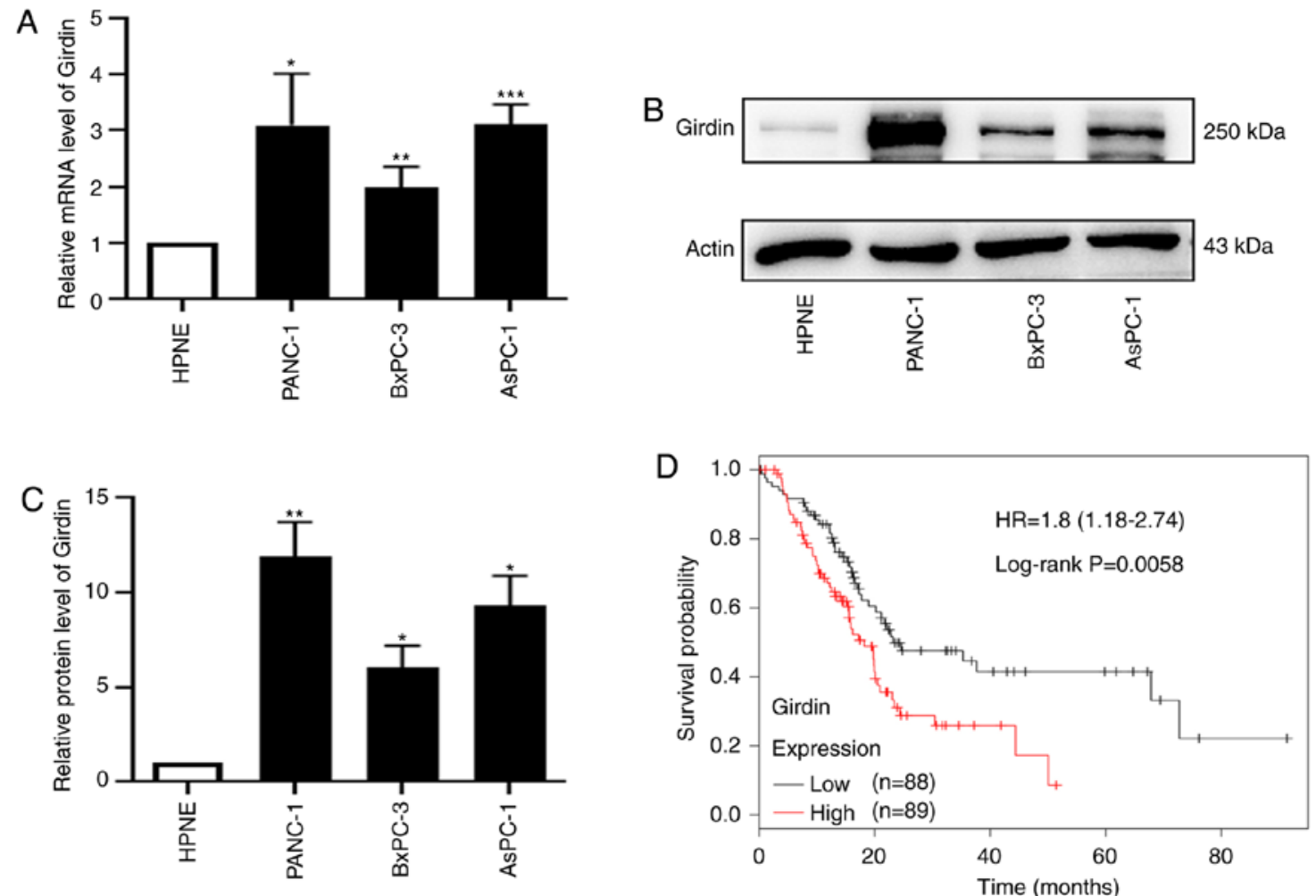

Figure 1. Girdin is upregulated in PDAC, and high expression of Girdin is associated with poor survival. (A) Relative mRNA expression of Girdin in three PDAC cell lines, PANC-1, BxPC-3 and AsPC-1, compared with the normal human pancreatic ductal cell line hTERT-HPNE was assessed by RT-qPCR (B) Protein levels of Girdin in the PDAC cell lines PANC-1, BxPC-3 and AsPC-1 and the normal human pancreatic ductal cell line hTERT-HPNE were confirmed by western blotting. (C) Histogram of the protein expression of Girdin in the PDAC cell lines PANC-1, BxPC-3 and AsPC-1 and the normal human pancreatic ductal cell line hTERT-HPNE. (D) Kaplan-Meier plotter analysis of GEPIA(http://gepia.cancer -pku.cn/) data indicated that a high level of Girdin was associated with poor survival; high $(\mathrm{n}=88)$ and low $(\mathrm{n}=89)$. Error bars were expressed as the mean $\pm \mathrm{SD}$, and the experiment was performed at least in triplicate. ${ }^{*} \mathrm{P}<0.05,{ }^{* *} \mathrm{P}<0.01$, and ${ }^{* * *} \mathrm{P}<0.001$ compared to HPNE. PDAC, pancreatic ductal adenocarcinoma; RT-qPCR, real-time quantitative polymerase chain reaction; Actin, internal reference; GEPIA, Gene Expression Profiling Interactive Analysis.

and AsPC-1 are highly invasive and poorly differentiated cell lines; however, BxPC-3 has low invasion abilities and is highly differentiated (32). The results revealed that the expression of Girdin in PANC-1 cells was higher than that in any other cell line, and BxPC-3 was poorly expressed among PDAC cell lines (Fig. 1B). A histogram of Girdin protein expression in PDAC cell lines is presented in Fig. 1C. Kaplan-Meier plotter analysis of the GEPIA data indicated that a high level of Girdin was associated with poor survival (Fig. 1D). Collectively, these results indicated that the high expression of Girdin in PDAC patients may be a candidate biomarker for improving treatment.

Knockdown of Girdin expression in PANC-1 and BxPC-3 cells by shRNA. The negative control (sh-NC) and Girdin-shRNA (sh-Girdin) recombinant adenoviruses were transfected into PDAC cells (PANC-1 and BxPC-3). The infection efficiency was first verified by GFP expression with fluorescence microscopy after infection with adenoviruses for $48 \mathrm{~h}$ (Fig. 2A and B). RT-qPCR and western blotting were performed to evaluate the expression level of Girdin in cells infected with Girdin-shRNA for 24 and $48 \mathrm{~h}$. The mRNA expression levels of Girdin were significantly decreased in the sh-Girdin group compared with the untreated (N) or the negative control (Fig. 2C) groups. Similarly, western blot analysis was also used and a significant decrease in Girdin protein levels after transfection with
sh-Girdin (Fig. 2D and E) was detected. Furthermore, the expression of Girdin was detected by immunofluorescence staining and the results obtained were similar to those aforementioned (Fig. 2F). These results indicated that following sh-Girdin infection, the expression of Girdin in PDAC cells was successfully suppressed.

Girdin-shRNA treatment inhibits the proliferation, invasion, and migration of PDAC cells. To identify the potential role of Girdin in PDAC progression, Girdin-knockdown PANC-1 and BxPC-3 cell lines were established by adenovirus transfection. Then, SRB experiments and colony formation assays were performed to evaluate the effect of Girdin on the growth of pancreatic cancer in vitro. Girdin knockdown significantly decreased PANC-1 and BxPC-3 cell viability compared with that in the sh-NC group (Fig. 3A and B). The colony-forming ability of pancreatic cancer cells was also significantly reduced by sh-Girdin (Fig. 3C). There is evidence that the expression of Girdin in breast cancer tissues is high, and a high level of Girdin is associated with a high risk of developing metastasis (12). However, whether Girdin has a biological function in the migration and invasion of PDAC has not been reported previously. To further determine whether Girdin is related to the metastasis of PDAC, Transwell experiments were performed to demonstrate that Girdin may regulate the migration and invasion of BxPC-3 and PANC-1 cells. The results 
A
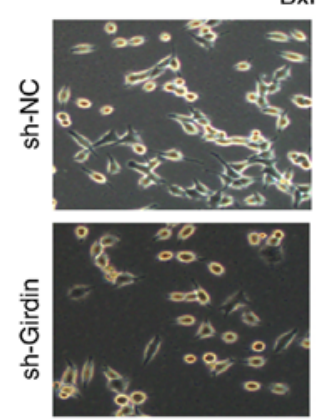

C

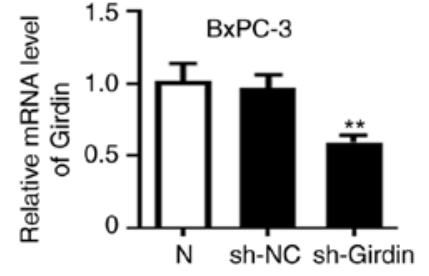

D

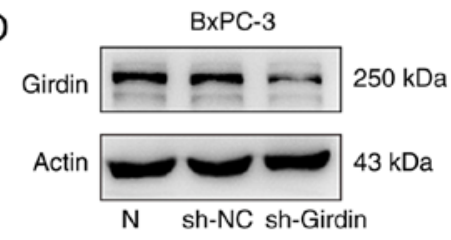

BPC-3
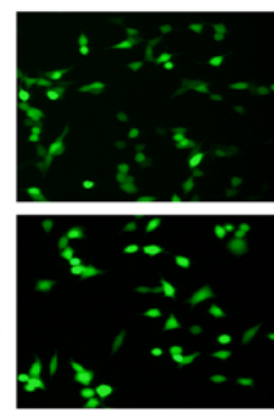

B
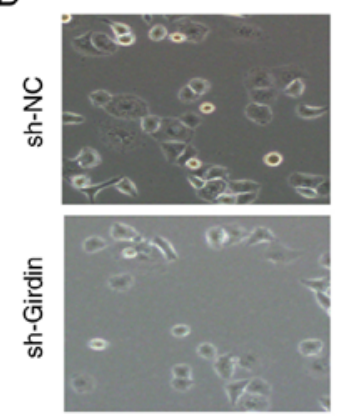

PANC-1

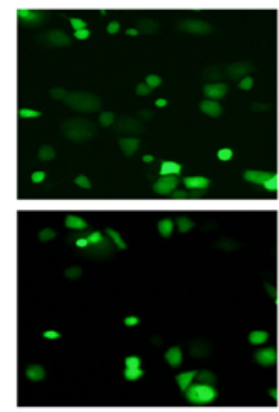

$\mathrm{F}$
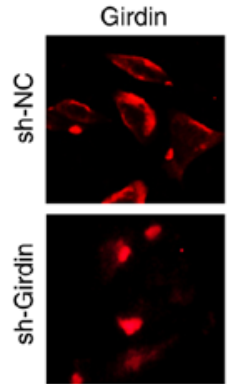

DAPI

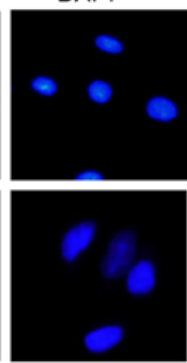

BxPC-3
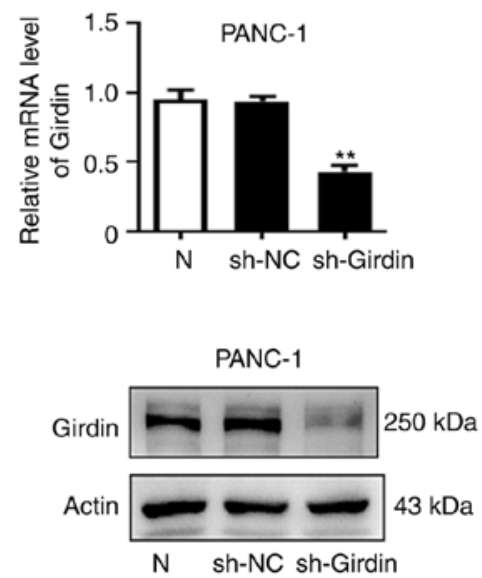

E
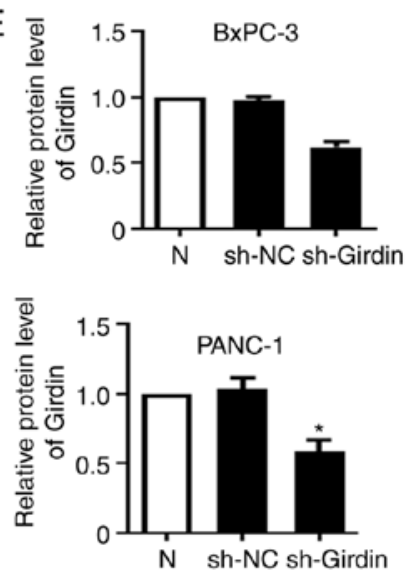

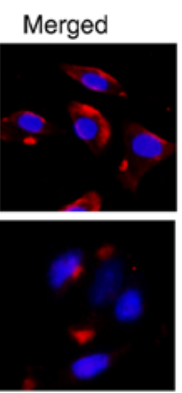

G

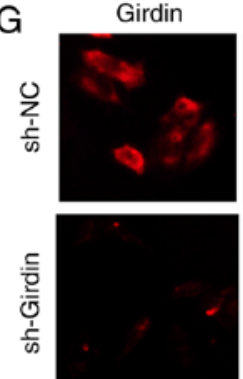

DAPI

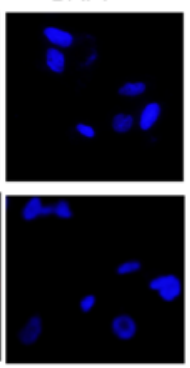

PANC-1

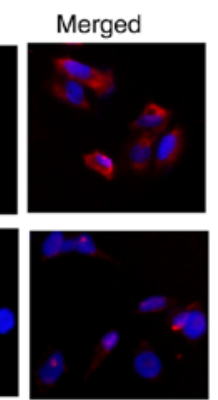

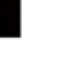

Figure 2. Girdin gene expression is decreased by a specific sh-RNA (sh-Girdin). (A and B) Fluorescence microscopy image with a scale bar of $100 \mu \mathrm{m}$ to confirm the transfection efficiency, indicating successful infection by sh-NC and sh-Girdin in the PANC-1 and BxPC-3 cells. (C) Real-time quantitative PCR was used to evaluate the mRNA level of Girdin in PDAC cell lines transfected with recombinant adenovirus. Actin was used as an internal control. (D and E) Girdin expression in BxPC-3 and PANC-1 cells was assessed by western blotting, and the protein level of Girdin was significantly decreased in the sh-Girdin groups. (F and G) PANC-1 and BxPC-3 cells were transfected with sh-NC or sh-Girdin and analyzed for protein expression and cellular distribution by immunofluorescence staining with an antibody against Girdin (red), showing that the cytoplasmic staining of Girdin was suppressed by sh-Girdin. Nuclei were stained and labeled with DAPI (blue). Scale bars, $100 \mu \mathrm{m}$. Significant results were obtained from at least three independent experiments; the data are presented as the mean $\pm \mathrm{SD}$. ${ }^{*} \mathrm{P}<0.05$, and ${ }^{* *} \mathrm{P}<0.01$ compared with sh-NC. PDAC, pancreatic ductal adenocarcinoma; sh-NC, non-targeting control short hairpin RNA; sh-Girdin, a specific short hairpin RNA of Girdin.

revealed that knockdown of Girdin suppressed cell migration and invasion (Fig. 3D and E). Collectively, these findings indicated that Girdin could promote the growth and metastasis of PDAC cells in vitro.

Girdin may interact with vimentin to affect TGF- $\beta$-induced $E M T$. EMT has been proposed to have various tumor functions, such as tumor initiation, malignant progression, tumor migration, metastasis and resistance to therapy (18). To further explore the underlying role of Girdin in the migration of PDAC cells, $48 \mathrm{~h}$ after transfection with sh-Girdin in PANC-1 and BxPC-3 cell lines, the metastasis-associated proteins MMP2/9 were detected by western blotting. As revealed from the results, the protein levels of MMP2 or MMP9 were decreased in PDAC cells transfected with sh-Girdin (Fig. 4A and B). These results were in accordance with the function of Girdin in cell migration. There is evidence that EMT is involved in PDAC progression (19-21). The Girdin/ $\beta$-catenin interaction may be a potential mechanism by which Girdin is involved in cell migration and invasion, and the Girdin/E-cadherin interaction may explain its involvement in cell-cell adhesion in skin cancer cells (11). Therefore, it was speculated that Girdin may be involved in the EMT pathway to affect the progression of pancreatic cancer. To confirm the mechanism by which Girdin 
A

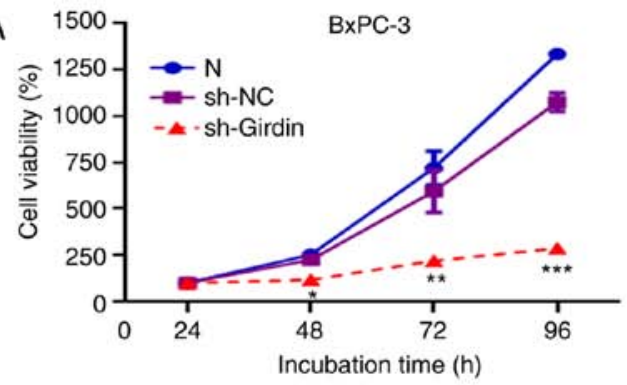

C
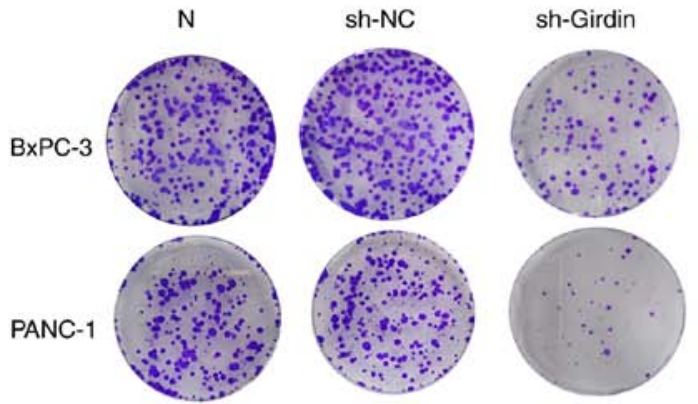

D

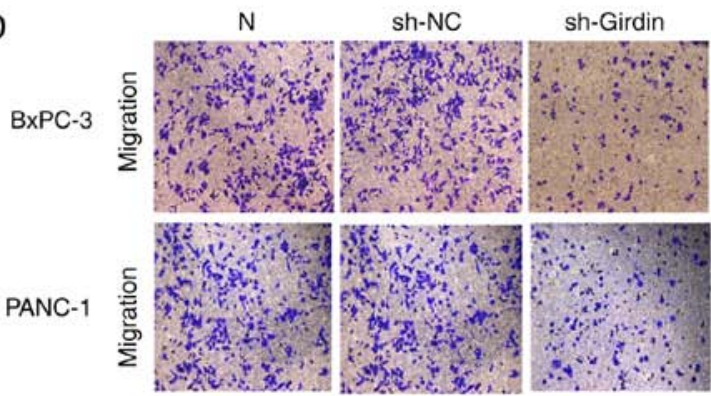

$E$

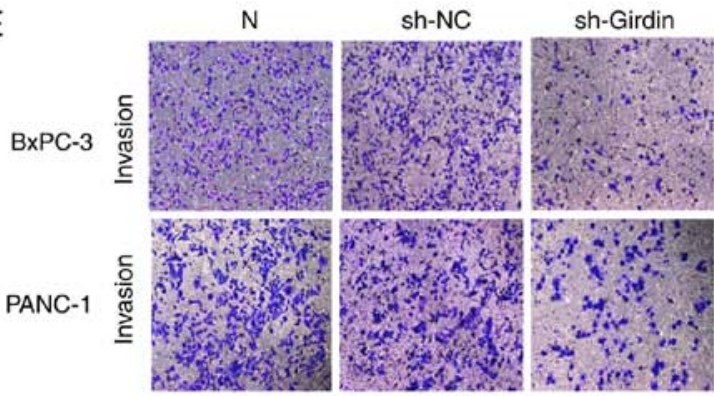

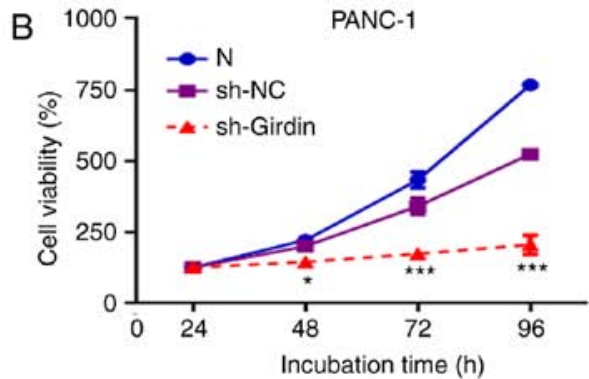
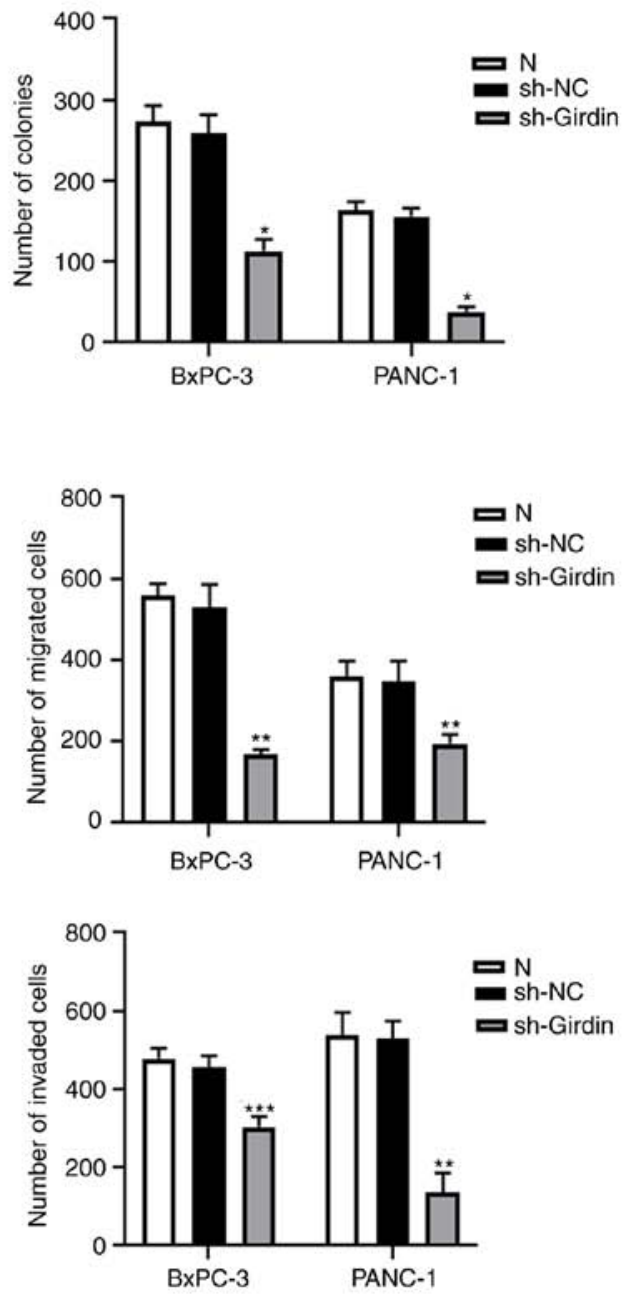

Figure 3. Effects of sh-Girdin on the proliferation, migration and invasion of pancreatic cancer cells. (A) The absorbance value of control cells and BxPC-3 cells transfected with sh-Girdin incubated for various time periods (24, 48,72 and $96 \mathrm{~h}$ ) was measured by SRB assay. Knockdown of Girdin significantly reduced proliferation after incubation for $48 \mathrm{~h}$. (B) The cell viability of BxPC-3 cells was measured by SRB assay at an absorbance of 490 nm. The proliferation of PANC-1 cells was inhibited by sh-Girdin. (C) The number of colonies was used to investigate proliferation after the cells were treated for 14 days, and knockdown of Girdin suppressed the formation of colonies in PDAC. (D and E) Transwell assays were used to confirm the metastasis of PDAC cells in vitro. Treatment with sh-Girdin reduced the number of migrating and invading cells in the lower chambers, scale bar, $100 \mu \mathrm{m}$. Three experiments were independently performed. The data are presented as the mean $\pm \mathrm{SD}$. ${ }^{*} \mathrm{P}<0.05,{ }^{* *} \mathrm{P}<0.01$, and ${ }^{* * *} \mathrm{P}<0.001$ compared with sh-NC. PDAC, pancreatic ductal adenocarcinoma; SRB, sulforhodamine B; sh-NC, non-targeting control short hairpin RNA; sh-Girdin, a specific short hairpin RNA of Girdin.

mediates PDAC cell motility, a mass spectrometric shotgun was used to distinguish Girdin immunocomplexes isolated from the lysate of PDAC cancer cells by tandem affinity purification. The EMT biomarker vimentin, which has a critical role in tumor progression, was identified in our experiment. Immunoprecipitation (IP) results demonstrated that vimentin was co-immunoprecipitated with the Girdin antibody; in addition, Girdin was co-immunoprecipitated with the vimentin antibody in PDAC cancer cells (Fig. 4C). Immunofluorescence staining of PANC-1 cells clearly revealed the co-localization of vimentin and Girdin in cells. In addition, similar phenomena were also observed in BxPC-3 cells (Fig. 4D). These results indicated that Girdin may interact with vimentin to affect the EMT of PDAC. The involvement of Girdin in regulating EMT biomarkers was investigated by examining the protein expression levels of E-cadherin, $\mathrm{N}$-cadherin and vimentin. TGF- $\beta$ was utilized to induce EMT in PDAC cells. The TGF- $\beta$ treatment time was $24 \mathrm{~h}$, and the concentration was 
A

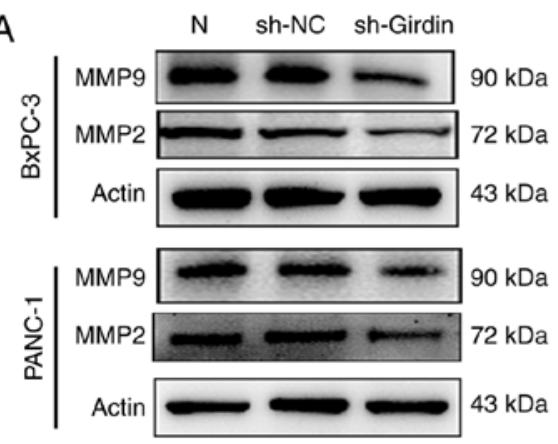

C
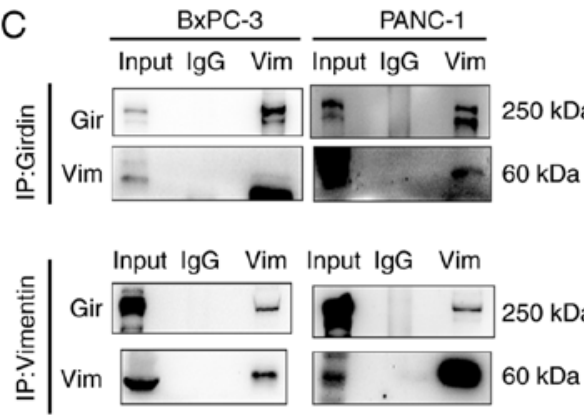

E

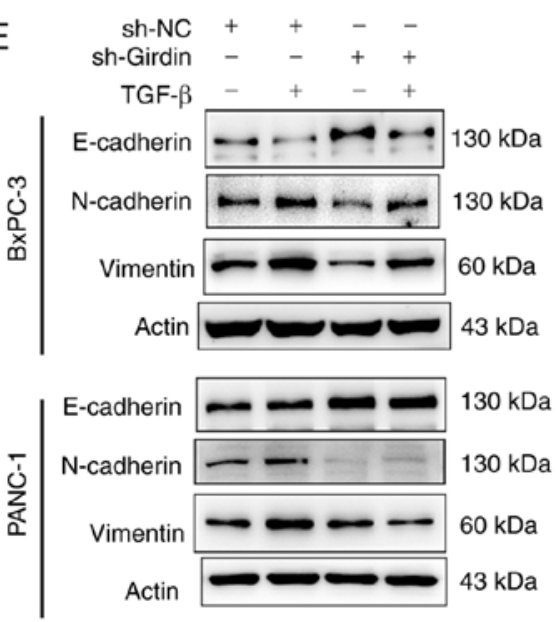

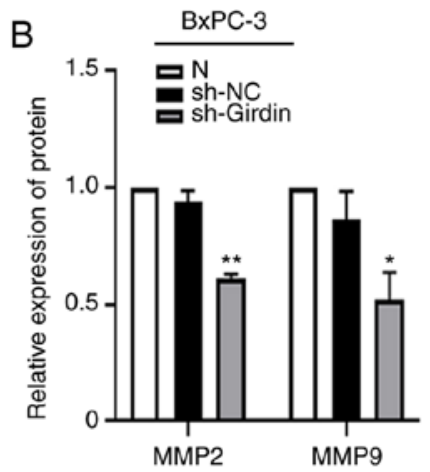
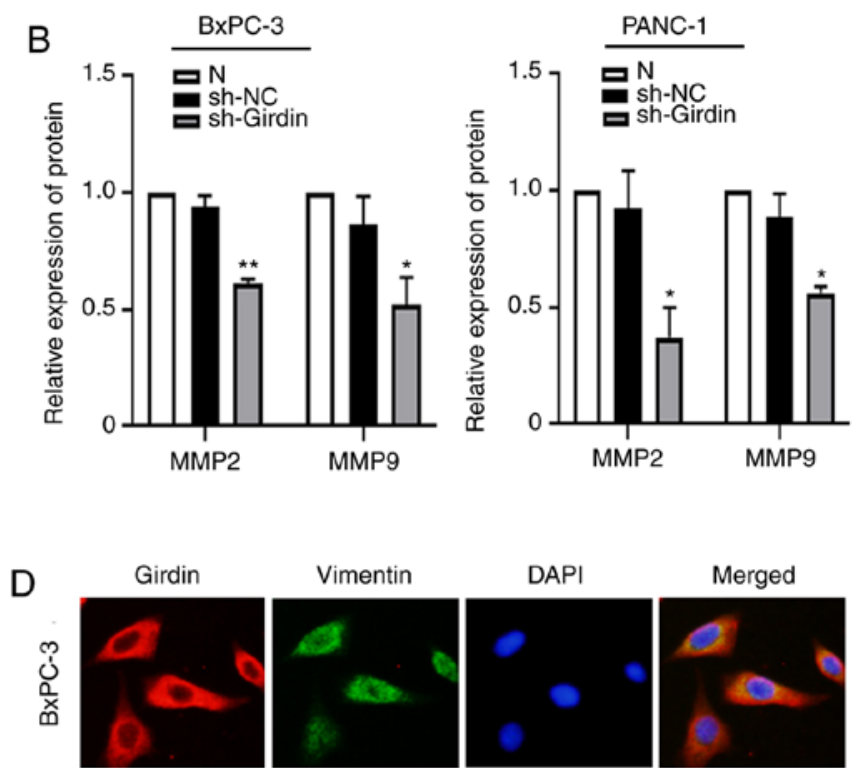

Vimentin
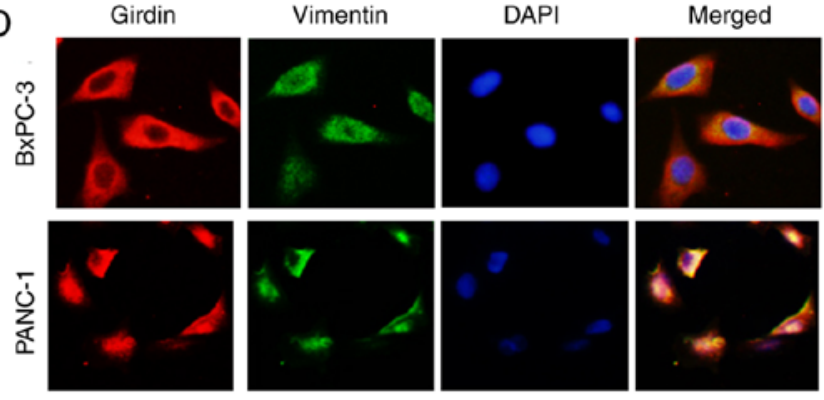

$\mathrm{F}$

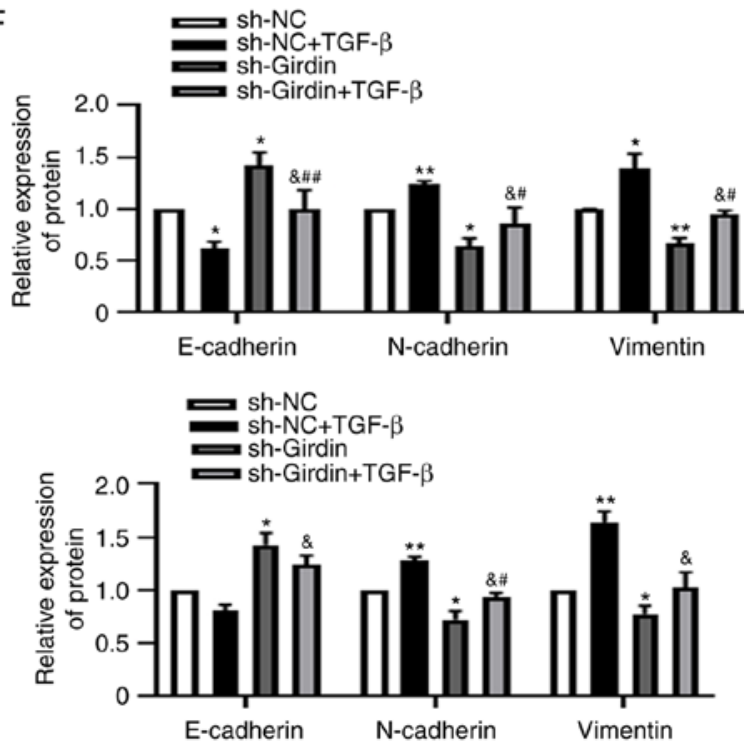

Figure 4. Girdin interacts with vimentin to reverse TGF- $\beta$-induced EMT. (A and B) Girdin was knocked down by sh-Girdin, and the cells were treated for 48 h; western blotting was used to analyze the protein levels of MMP2 and MMP9 in the PDAC cell lines. (C) Girdin-interacting proteins were assessed in PANC-1 and BxPC-3 cells by co-IP, which revealed the endogenous Girdin-vimentin interaction. The lysates were analyzed by western blotting. (D) Endogenous Girdin and vimentin in PANC-1 and BxPC-3 cells was detected by immunofluorescence staining. The cells were not treated before fixation with $4 \%$ paraformaldehyde, and the cellular location of Girdin (red) and vimentin (green) was detected by immunofluorescence staining using anti-Girdin and anti-vimentin antibodies. The nuclei were stained with DAPI (blue) and visualized by fluorescence microscopy at a scale bar of $100 \mu \mathrm{m}$. (E and F) The EMT markers E-cadherin, $\mathrm{N}$-cadherin and vimentin were evaluated by western blotting. As revealed, sh-Girdin reduced the protein levels of N-cadherin and vimentin compared with those in the sh-NC group, and the TGF- $\beta$-induced change in the expression of these markers was reversed by sh-Girdin. Three experiments were independently performed. The data are presented as the mean $\pm \mathrm{SD}$. ${ }^{*} \mathrm{P}<0.05$, and ${ }^{* *} \mathrm{P}<0.01$ compared with sh-NC; ${ }^{\circledR} \mathrm{P}<0.05$, compared with sh-NC co-incubated with TGF- $\beta$; ${ }^{\#} \mathrm{P}<0.05$, and ${ }^{\# \#} \mathrm{P}<0.01$ compared with sh-Girdin. PDAC, pancreatic ductal adenocarcinoma; Gir, Girdin; Vim, Vimentin; TGF- $\beta$, transforming growth factor- $\beta$; EMT, epithelial-mesenchymal transition; sh-NC, non-targeting control short hairpin RNA; sh-Girdin, a specific short hairpin RNA of Girdin.

$10 \mu \mathrm{M}$. Compared with the untreated group, the expression level of E-cadherin, an epithelial phenotype biomarker, was effectively increased, and the expression levels of N-cadherin and vimentin, mesenchymal phenotype biomarkers, were significantly reduced in the sh-Girdin group (Fig. 4E and F). Although the EMT biomarker E-cadherin was not significantly reduced in PANC-1 cells, $\mathrm{N}$-cadherin and vimentin expression was significantly increased by TGF- $\beta$ in the PANC- 1 and BxPC-3 cells treated by sh-NC with TGF- $\beta$ compared to the sh-NC group. It was also revealed that TGF- $\beta$-induced EMT was reversed by sh-Girdin in the PANC-1 and BxPC-3 cells in the sh-NC with TGF- $\beta$ group compared to the sh-Girdin with 
A

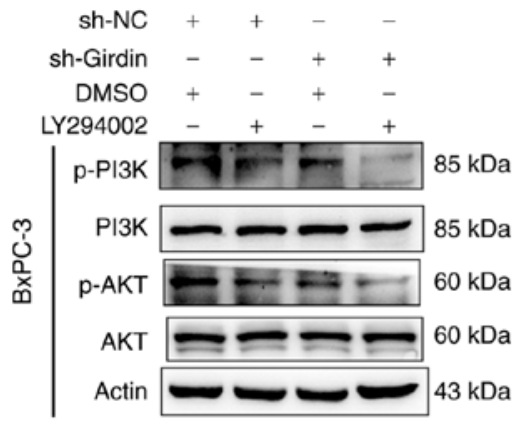

B

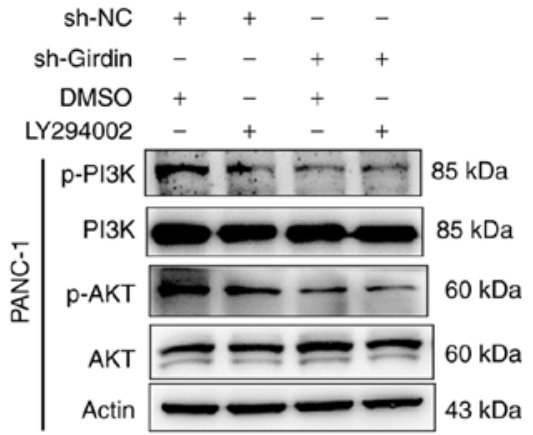

C

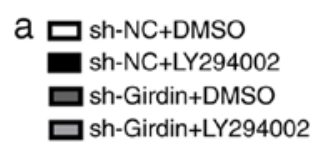

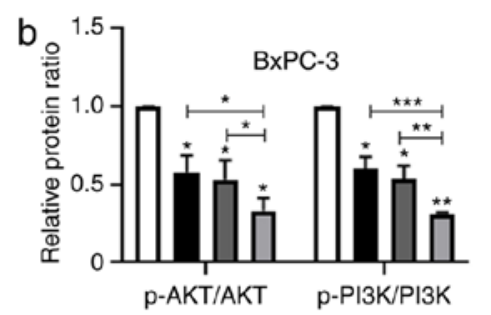

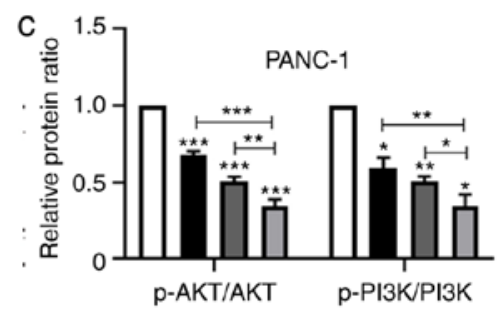

D

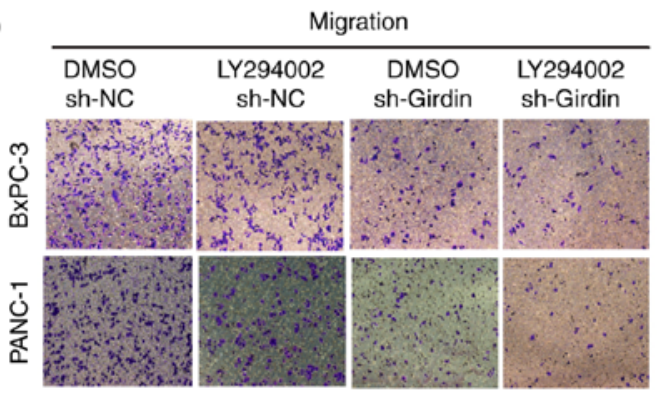

E

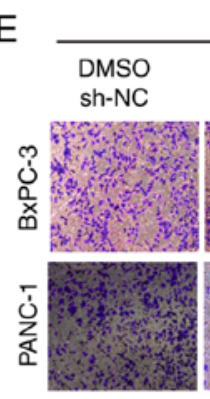

Invasion

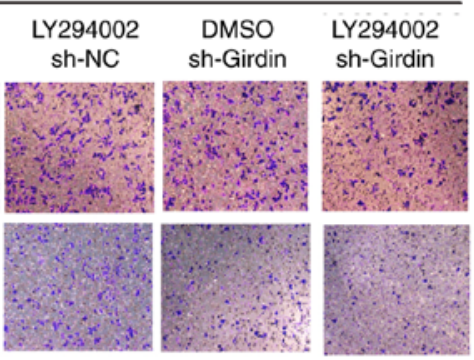

F

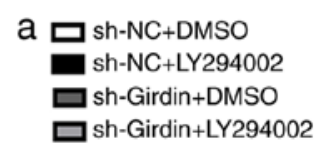

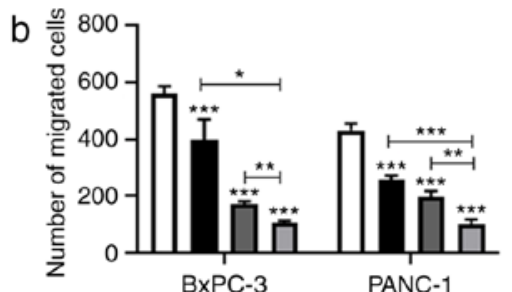

Figure 5. Effects of Girdin knockdown on the inhibition of metastasis in PDAC are enhanced by LY294002. (A and B) Western blot analysis of the level of phosphorylation of PI3K and Akt expression in PANC-1 and BxPC-3 cells. (C) Statistical analysis of the ratio of phosphorylated protein to total protein. Knockdown of Girdin inactivated phosphorylation of the PI3K/AKT pathway. LY294002 enhanced the inhibitory effect of Girdin knockdown on PDAC. (D and E) The migration and invasion abilities of PDAC cells were evaluated by Transwell assay. (F) Statistical analysis of PDAC cell migration and invasion; scale bar, $100 \mu \mathrm{m}$. Three experiments were independently performed. The data are presented as the mean $\pm \mathrm{SD}$. ${ }^{*} \mathrm{P}<0.05,{ }^{* *} \mathrm{P}<0.01$, and ${ }^{* * *} \mathrm{P}<0.001$. $\mathrm{PDAC}$, pancreatic ductal adenocarcinoma; DMSO, dimethyl sulfoxide; sh-NC, non-targeting control short hairpin RNA; sh-Girdin, a specific short hairpin RNA of the Girdin.

TGF- $\beta$ (Fig. 4E and F). Collectively, the potential mechanism by which Girdin affects cell migration may occur through its interaction with vimentin.

Girdin inhibition suppresses cell migration and invasion through the PI3K/AKT signaling pathway. There is evidence suggesting that Girdin is a substrate of AKT and has an important role in regulating the migration of cancer cells, such as colon cancer cells $(18,22,25)$. To the best of our knowledge, we were the first to further explore the potential mechanism by which sh-Girdin inhibits pancreatic cancer cell migration and invasion. Thus, the effect of Girdin on PI3K/Akt pathway activation in PDAC cells was examined. Western blotting was performed to analyze the level of phosphorylation of
PI3K and AKT, and the total protein level of PI3K and AKT. Consistent with previous results, knockdown of Girdin significantly inhibited the phosphorylation of PI3K and AKT in PANC-1 and BxPC- 3 cells compared with that in the negative control cells (Fig. 5A-C). These results revealed that Girdin knockdown inactivated the PI3K/Akt signaling pathway. Furthermore, it was demonstrated that treatment with the PI3K inhibitor LY294002 significantly enhanced the inhibitory effects of sh-Girdin on PDAC cells (Fig. 5A-C). In addition, a Transwell assay was used to confirm that Girdin regulates PDAC cell migration and invasion via the PI3K/AKT pathway. As the results revealed, the PI3K inhibitor LY294002 further increased the inhibitory effect of sh-Girdin on PANC-1 cell migration and invasion in the sh-Girdin with LY294002 group 
A

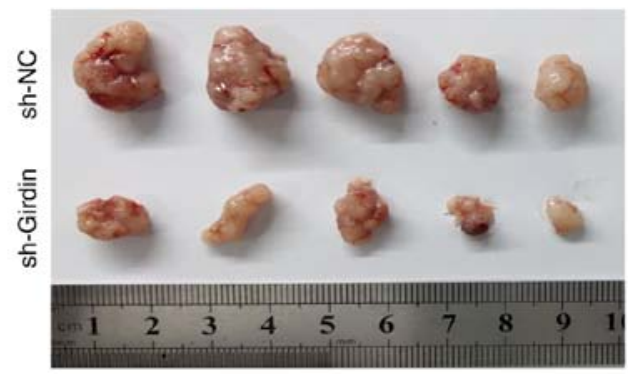

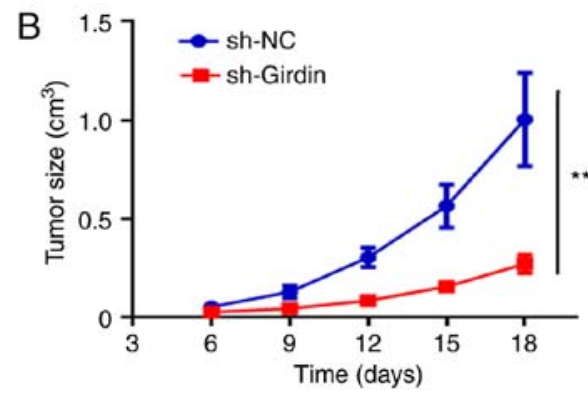
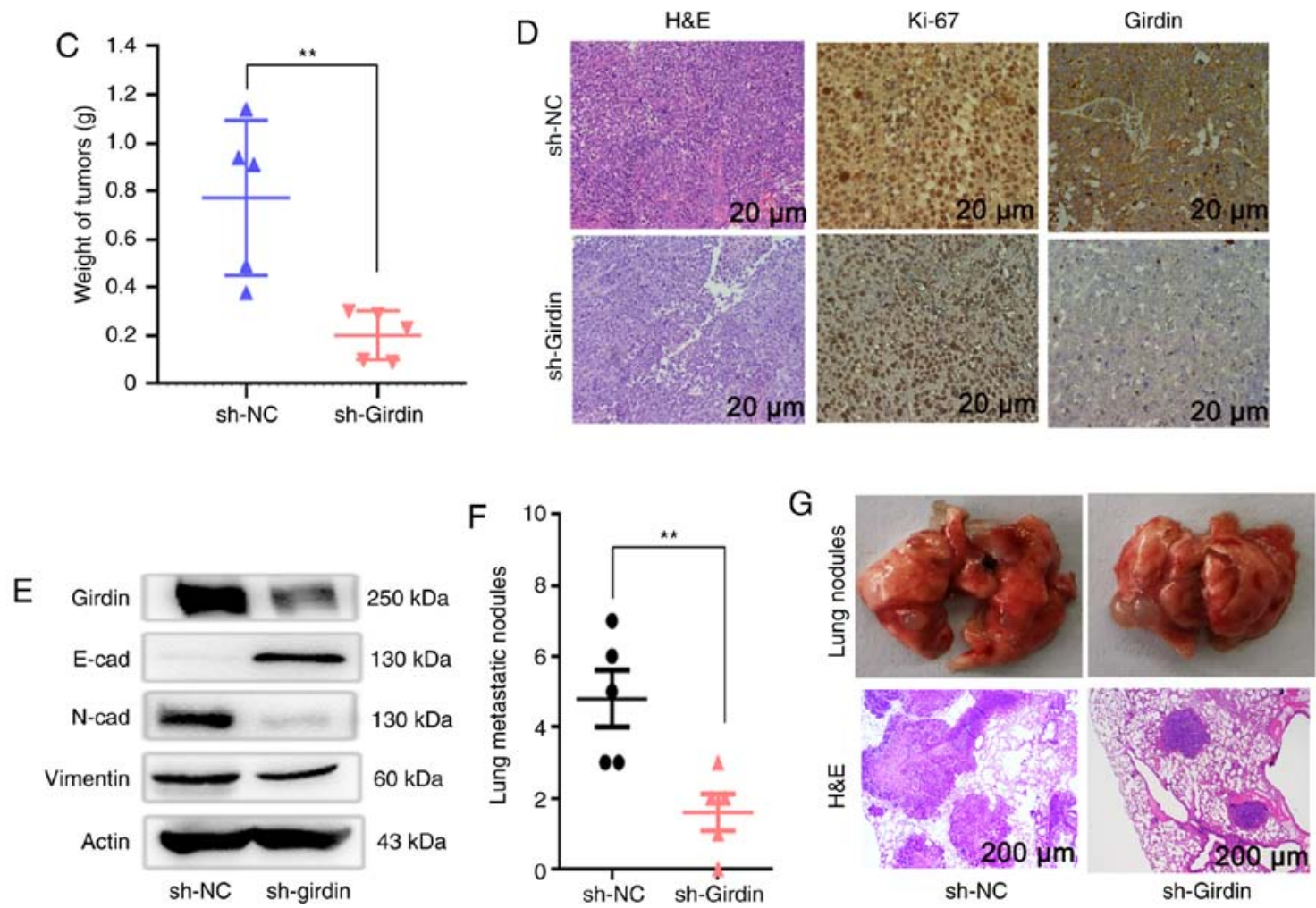

Figure 6. Girdin regulates PDAC cell tumor growth and metastasis in vivo. (A) Stable Girdin-knockdown BxPC-3 cells were injected under the skin of nude mice. (B) Tumor volumes were first calculated after injection for 6 days and measured every three days after. (C) The tumors were dissected and measured, and the tumor weights in the sh-Girdin group were reduced compared to those in the sh-NC group. (D) Immunostaining revealed H\&E staining and staining using antibodies against Ki-67 and Girdin in xenograft tumors. The levels of Ki-67 and Girdin in the samples from the sh-Girdin group were lower than those in the control group. Scale bar, $20 \mu \mathrm{m}$. (E) The protein level of Girdin was also detected by western blotting, and the changes in EMT markers were similar to those observed in vitro. (F) Stable Girdin-knockdown BxPC-3 cells were injected into the mice through the tail vein, and six weeks later, the lung metastasis in the sh-Girdin group was significantly decreased compared with that in the sh-NC group based on the number of nodules and the area of H\&E staining. Scale bar, $200 \mu \mathrm{m}$. The tumor weight and the lung metastatic nodules are presented as the mean $\pm \mathrm{SD}$. ${ }^{* *} \mathrm{P}<0.01 \mathrm{compared}$ with sh-NC group. PDAC, pancreatic ductal adenocarcinoma; H\&E, hematoxylin and eosin; EMT, epithelial-mesenchymal transition; sh-NC, non-targeting control short hairpin RNA; sh-Girdin, a specific short hairpin RNA of Girdin.

compared to the sh-Girdin with DMSO group. Similar results were observed in BxPC-3 cells (Fig. 5D-F). These results indicated that Girdin knockdown may suppress pancreatic cell migration and invasion by inactivating the PI3K/Akt signaling pathway.

Knockdown of Girdin inhibits the growth and metastasis of PDAC cells in vivo. A xenograft mouse model was further applied to confirm the aforementioned in vitro findings. BxPC-3 cells were stably transfected with sh-Girdin or negative control sh-NC. Then, control cells and BxPC-3 cells with stable knockdown of Girdin were inoculated into male nude mice to determine whether Girdin affects PDAC cell tumorigenesis in vivo. In this study, On the 18th day after injection, compared with the negative control containing the sh-RNA vector (sh-NC), the tumors formed by BxPC-3 cells with Girdin-shRNA (sh-Girdin) clearly grew significantly slower in male nude mice (Fig. 6A and B). Moreover, the weights of tumors from the sh-Girdin group were significantly lighter than those from the sh-NC group (Fig. 6C). Images from these experiments revealed $\mathrm{H} \& \mathrm{E}$ and $\mathrm{Ki}-67$ staining along with Girdin staining of xenograft tumors from the sh-NC and sh-Girdin groups. Tumors formed from BxPC-3 cells transfected with sh-Girdin exhibited decreased expression of $\mathrm{Ki}-67$ compared with that in tumors formed from sh-NC cells. Similarly, a positive decrease in Girdin was confirmed in the tumors formed from the sh-Girdin group by immunohistochemistry (Fig. 6D). Furthermore, the protein 
level of Girdin was also inhibited by sh-Girdin compared with the sh-NC group in vivo (Fig. 6E). To further investigate whether sh-Girdin affected tumor cell migration in nude mice, western blotting was also used to detect EMT biomarkers. Consistent with the function in vitro, the protein expression of $\mathrm{N}$-cadherin and vimentin was suppressed, and the expression of E-cadherin was increased in vivo (Fig. 6E). Moreover, the lung metastasis of nude mice was assessed to demonstrate that Girdin is involved in malignant tumor metastasis. In the present study, stable Girdin-knockdown BxPC-3 cells and sh-NC BxPC-3 cells were injected into two groups of mice through the tail vein. Six weeks later, lung metastasis in the sh-Girdin group was significantly decreased compared with that in the sh-NC group, not only in the number of nodules but was also observed with the area of $H \& E$ staining (Fig. 6F and G). Therefore, these results indicated that knockdown of Girdin could exert an antitumor effect in vivo, which further demonstrated the important role of Girdin in PDAC growth and metastasis.

\section{Discussion}

Among pancreatic tumors, PDAC is the most common type, and the poor prognosis of PDAC is mainly related to its metastasis (33). Despite significant attention being paid to enhancing early detection strategies in PDAC patients, $85 \%$ of patients are diagnosed with metastatic or locally advanced PDAC (34). However, the underlying mechanisms of PDAC metastasis are unclear. Our previous study reported that Girdin was highly expressed in pancreatic cancer tissues and was associated with pathological grade (30). In the present study, it was revealed that the level of Girdin was upregulated in PDAC cell lines and that high Girdin expression was related to poor prognosis in PDAC patients by analyzing GEPIA data. Therefore, the present research mainly explored the mechanism of Girdin in pancreatic cancer metastasis. Girdin was knocked down in PDAC cell lines, and the results revealed that cell viability and mobility in vitro were inhibited. In addition, knockdown of Girdin suppressed PDAC growth and metastasis in vivo. The molecular mechanism assays indicated that Girdin may activate the PI3K/AKT signaling pathway, which is related to the invasion and migration of PDAC cells. Mechanistic investigations also elucidated that Girdin may interact with vimentin to suppress TGF- $\beta$-induced EMT in pancreatic cancer.

To date, numerous studies have revealed that Girdin plays an important role in tumorigenesis and progression (27-30). Evidence that Girdin plays a key role in human PDAC development and progression was also provided, partially by activating the PI3K/AKT signaling pathway. It was revealed that the mRNA expression of Girdin and the protein levels of Girdin were increased in PANC-1, AsPC-1 and BxPC-3 (human PDAC cell lines) compared with HPNE (a normal human pancreatic epithelial cell line).

In our previous study, IHC staining also demonstrated higher protein expression of Girdin in PDAC tissues compared to matched adjacent cancer tissues (30). The expression of Girdin was also demonstrated to be higher in breast cancer and colon cancer tissues than in adjacent normal tissues (29-30). The functional role of Girdin revealed in the present study was also similar to previous studies in other cancers $(20,24,25)$.
The knockdown of Girdin in pancreatic cancer cells not only suppressed the proliferation of PDAC in vitro but also suppressed the growth of PDAC in vivo. Furthermore, Girdin knockdown also decreased the metastasis of PDAC. Collectively, this evidence indicated that Girdin may play a critical role in the development and progression of PDAC. The present results suggest a new potential intervention target for PDAC metastasis treatment that may improve the prognosis of PDAC patients.

Cancer cell invasion and metastasis are primarily responsible for most cancer-associated deaths, including those related to PDAC (2). EMT is an important developmental process in the distant metastasis of pancreatic cancer (35). EMT is also linked to invasion and dissemination in numerous types of cancer (13-14). Epithelial cells undergo various biochemical changes, including the loss of epithelial characteristics and the acquisition of mesenchymal properties (11-12). The characteristic changes in EMT are the loss of epithelial marker E-cadherin and the increase in mesenchymal markers vimentin and $\mathrm{N}$-cadherin $(34,36)$. Recently, it was revealed that downregulation of Girdin suppressed breast cancer and neuroglioma migration and invasion in vitro and that Girdin may interact with the epithelial marker E-cadherin to regulate cell-cell adhesion $(24,26,37)$. Similar to a previous study (21), it was observed that Girdin may interact with the mesenchymal marker vimentin to affect pancreatic cancer cell migration. The results indicated that the Girdin knockdown-induced increase in E-cadherin and decrease in N-cadherin may at least partly contribute to vimentin- and MMP-mediated invasion. TGF- $\beta$ is a crucial driver of EMT and has been demonstrated to regulate cell mobility and EMT progression in pancreatic cancer (15-16). It was hypothesized that Girdin may also affect PDAC progression by being involved in TGF- $\beta$-induced EMT. Therefore, it was explored whether Girdin regulated the progression of TGF- $\beta$-induced EMT in PDAC. Evidence was provided that with increasing concentrations and 24-h TGF- $\beta$ treatment, the EMT markers in PDAC were significantly altered, which is similar to previous studies $(38,39)$, and knockdown of Girdin effectively reversed TGF- $\beta$-induced EMT. These results demonstrated the potential role of Girdin suppression in reversing EMT in PDAC. This research, to the best of our knowledge, is the first to highlight the potential roles of the Girdin-vimentin complex in the EMT process. The present results revealed that Girdin may be a novel actin protein that has a significant effect on tumor EMT progression, which is associated with distant metastasis and could be a potential metastatic target for the treatment of PDAC.

The PI3K/AKT pathway is a classic signaling pathway associated with the development and progression of numerous types of cancers, and the PI3K/AKT pathway is aberrantly activated in the disease progression of pancreatic cancer (40-41). In pancreatic cancer cells, evidence has revealed that the $\mathrm{PI} 3 \mathrm{~K} / \mathrm{AKT}$ pathway plays a crucial role in regulating cellular metabolism, proliferation, metastasis and survival (42-44). It has also been revealed that the PI3K/AKT pathway is a key regulator in pancreatic tumorigenesis and may be a treatment target of other cancers (45). It has been reported that knockdown of the expression of Girdin inhibits the migration and invasion ability of glioma cancer cells by suppressing the phosphorylation/activation of the PI3K/AKT pathway (46). 
Mechanistically, Girdin is also known as Akt phosphorylation enhancer because it can be regarded as a substrate for the phosphorylation of AKT $(17,47)$. Therefore, further study of the role of Girdin in the PI3K/AKT pathway may be beneficial to reveal the underlying molecular mechanism of the regulatory effect of Girdin on PDAC. As revealed in the present study, the knockdown of Girdin decreased the levels of p-Akt and p-PI3K via the PI3K/AKT pathway in PDAC cell lines, which was enhanced by treatment with the PI3K inhibitor LY294002. The metastatic ability of Girdin through inhibition of PI3K/AKT was further determined, and knockdown of Girdin and inhibition of the PI3K/AKT pathway, significantly decreased PDAC migration. Thus, it was concluded that the promoting effect of Girdin on PDAC cells partly contributed to the aberrant activation of PI3K/AKT signaling.

In the present study, a novel actin protein, Girdin, was first identified, whose knockdown by recombinant adenoviruses suppressed the growth and metastasis of PDAC cells. Further study involving in vivo tumorigenicity assays and metastasis assays demonstrated that Girdin knockdown also suppressed PDAC growth and metastasis. In addition, it was revealed that the Girdin-related suppression of PDAC cell invasion and metastasis may rely on the inhibition of aberrant PI3K/Akt pathway activation. Moreover, whether Girdin interacts with vimentin to suppress TGF- $\beta$-induced EMT was also investigated. In summary, the present findings revealed that Girdin may contribute to the EMT and metastasis of PDAC. Girdin may act as a promising biological marker and a candidate metastatic target for the treatment of pancreatic cancer patients. Although the mechanisms by which Girdin elicits its effects on PDAC cell apoptosis were reported in our previous study (30), its potential effects on autophagy should be further investigated and verified. To the best of our knowledge, this is the first study that investigates the metastasis and TGF- $\beta$-induced EMT effect of Girdin on PDAC. We acknowledge several limitations in the present study. First, there was no analysis of the correlation between Girdin and vimentin in pancreatic cancer tissues, and there was no in-depth study on the binding region of Girdin and vimentin. Thus, further studies are required to reveal the underlying mechanism by which the Girdin/vimentin axis regulates EMT in pancreatic cancer.

\section{Acknowledgements}

All of the authors gratefully thank Professors Xiubin Liang and Dongming Su, Department of Pathophysiology, School of Basic Medical Sciences (Nanjing Medical University, Nanjing, China) for providing an available experimental platform and experimental guidance and Ms. Min Li, a research assistant, for experimental management and assistance.

\section{Funding}

Funding for the present study was mainly provided from the National Natural Science Foundation of China (nos. 30972910 and 81172269); the Six Talent Peak Funding Projects of Jiangsu Province (WSW-032); the Natural Science Foundation of Jiangsu Province (no. 050104313) and the key Research and Development Projects of Suqian (S201809).

\section{Availability of data and materials}

The datasets used during the present study are available from the corresponding author upon reasonable request.

\section{Authors' contributions}

WW, HC, WH and CY conceived the study and designed the experiments. WW, SW and KW performed the experiments on cell culture, construction of the xenograft and lung metastasis model of subcutaneous tumor formation in a nude mouse, RT-qPCR and western blot analysis. XL, CL and LL performed analysis of data and interpretation of data and critically reviewed the manuscript for important intellectual content. WW, HC, WG and CY drafted the manuscript and integrated all the results. All the authors approved the manuscript preparation and submission.

\section{Ethics approval and consent to participate}

This study strictly followed the guidelines issued [Eighth Edition (2011)] by the National Institutes of Health for the Care and Use of Laboratory Animals. The Animal Ethics and Welfare Committee (AEWC) of Nanjing Medical College provided protocol approval (IACUC-1601161)

\section{Patient consent for publication}

Not applicable.

\section{Competing interests}

The authors declare that they have no competing interests.

\section{References}

1. Owens DK, Davidson KW, Krist AH, Barry MJ, Cabana M, Caughey AB, Curry SJ, Doubeni CA, Epling JW, Kubik M, et al: Screening for pancreatic cancer. JAMA 322: 438, 2019.

2. Bray F, Ferlay J, Soerjomataram I, Siegel RL, Torre LA and Jemal A: Global cancer statistics 2018: GLOBOCAN estimates of incidence and mortality worldwide for 36 cancers in 185 countries. CA Cancer J Clin 68: 394-424, 2018.

3. Moffat GT, Epstein AS and O'Reilly EM: Pancreatic cancer-A disease in need: Optimizing and integrating supportive care. Cancer 125: 3927-3935, 2019.

4. Rahib L, Fleshman JM, Matrisian LM and Berlin JD: Evaluation of pancreatic cancer clinical trials and benchmarks for clinically meaningful future trials: A systematic review. JAMA Oncol 2: 1209-1216, 2016.

5. Rahib L, Smith BD, Aizenberg R, Rosenzweig AB, Fleshman JM and Matrisian LM: Projecting cancer incidence and deaths to 2030: The unexpected burden of thyroid, liver, and pancreas cancers in the United States. Cancer Res 74: 2913-2921, 2014

6. Shi Y, Gao W, Lytle NK, Huang P, Yuan X, Dann AM, Ridinger-Saison M, Del Giorno KE, Antal CE, Liang G, et al: Targeting LIF-mediated paracrine in- teraction for pancreatic cancer therapy and monitoring. Nature 569: 131-135, 2019.

7. Fox RG, Lytle NK, Jaquish DV, Park FD, Ito T, Bajaj J, Claire S, Koechlein CS, Zimdahl B, Yano M, et al: Image based detection and targeting of therapy resistance in pancreatic adenocarcinoma. Nature 534: 407-411, 2016.

8. Karmazanovsky G, Fedorov V, Kubyshkin V and Kotchatkov A: Pancreatic head cancer: Accuracy of CT in determination of resectability. Abdom Imaging 30: 488-500, 2005.

9. Strobel O, Neoptolemos J, Jager D and Buchler MW: Optimizing the outcomes of pancreatic cancer surgery. Nat Rev Clin Oncol 16: 11-26, 2019. 
10. Amrutkar M and Gladhaug I: Pancreatic cancer chemoresistance to gemcita-bine. Cancers 9: 157, 2017.

11. Feng H, Zhao X, Guo Q, Feng Y, Ma M, Guo W, Dong X, Deng C, Li C, Song X, et al: Autophagy resists EMT process to maintain retinal pigment epithelium homeostasis. Int J Biol Sci 15: 507-521, 2019

12. Pastushenko I and Blanpain C: EMT transition states during tumor pro-gression and metastasis. Trends Cell Biol 29: 212-226, 2019.

13. Rhim AD, Mirek ET, Aiello NM, Maitra A, Bailey JM, McAllister F, Reichert M, Beatty GL, Rustgi AK, Vonderheide RH, et al: EMT and dissemination precede pancreatic tumor formation. Cell 148: 349-361, 2012.

14. De Craene B and Berx G: Regulatory networks defining EMT during cancer initiation and progression. Nat Rev Cancer 13: 97-110, 2013

15. Costanza B, Rademaker G, Tiamiou A, De Tullio P, Leenders J, Blomme A, Bellier J, Bianchi E, Turtoi A, Delvenne P, et al: Transforming growth factor beta-induced, an extracellular matrix interacting protein, enhances glycolysis and promotes pancreatic cancer cell migration. Int J Cancer 145: 1570-1584, 2019.

16. Zhang N, Liu Y, Wang Y, Zhao M, Tu L and Luo F: Decitabine reverses TGF- $\beta 1$-induced epithelial-mesenchymal transition in non-small-cell lung cancer by regulating miR-200/ZEB axis. Drug Des Devel Ther 11: 969-983, 2017.

17. Enomoto A, Murakami H, Asai N, Morone N, Watanabe T, Kawai K, Murakumo Y, Usukura J, Kaibuchi K and Takahashi M: Akt/PKB regulates actin organization and cell motility via Girdin/APE. Dev Cell 9: 389-402, 2005.

18. Weng L, Enomoto A, Ishida-Takagishi $\mathrm{M}$, Asai $\mathrm{N}$ and Takahashi M: Girding for migratory cues: Roles of the Akt substrate Girdin in cancer progression and angiogenesis. Cancer Sci 101: 836-842, 2010.

19. Anai M, Shojima N, Katagiri H, Ogihara T, Sakoda H, Onishi Y, Ono H, Fujishiro M, Fukushima Y, Horike N, et al: A novel protein kinase B (PKB)/AKT-binding protein enhances PKB kinase activity and regulates DNA synthesis. J Biol Chem 280: 18525-18535, 2005.

20. Jiang P, Enomoto A, Jijiwa M, Kato T, Hasegawa T, Ishida M, Sato T, Asai N, Murakumo Y and Takahashi M: An actin-binding protein Girdin regulates the motility of breast cancer cells. Cancer Res 68: 1310-1318, 2008.

21. Wang X, Enomoto A, Weng L, Mizutani Y, Abudureyimu S, Esaki N, Tsuyuki Y, Chen C, Mii S, Asai N, et al: Girdin/GIV regulates collective cancer cell migration by controlling cell adhesion and cytoskeletal organization. Cancer Sci 109: 3643-3656, 2018.

22. Natsume A, Kato T, Kinjo S, Enomoto A, Toda H, Shimato S, Ohka F, Motomura K, Kondo Y, Miyata T, et al: Girdin maintains the stemness of glioblastoma stem cells. Oncogene 31 : 2715-2724, 2012

23. Yamamura Y, Asai N, Enomoto A, Kato T, Mii S, Kondo Y, Ushida K, Niimi K, Tsunoda N, Nagino M, et al: Akt-Girdin signaling in cancer-associated fibroblasts contributes to tumor progression. Cancer Res 75: 813-823, 2015.

24. Choi J, Kim KH, Oh E, Shin YK, Seo J, Kim S, Park S and Choi Y: Girdin protein expression is associated with poor prognosis in patients with invasive breast cancer. Pathology 49 : 618-626, 2017

25. Ghosh P, Tie J, Muranyi A, Singh S, Brunhoeber P, Leith K, Bowermaster R, Liao Z, Zhu Y, LaFleur B, et al: Girdin (GIV) expression as a prognostic marker of recurrence in mismatch repair-proficient stage ii colon cancer. Clin Cancer Res 22: 3488-3498, 2016

26. Shibata T, Matsuo Y, Shamoto T, Hirokawa T, Tsuboi K, Takahashi $\mathrm{H}$, Ishiguro $\mathrm{H}$, Kimura $\mathrm{M}$, Takeyama $\mathrm{H}$ and Inagaki $\mathrm{H}$ : Girdin, a regulator of cell motility, is a potential prognostic marker for esophageal squamous cell carcinoma. Oncol Rep 29: 2127-2132, 2013

27. Gu F, Wang L, He J, Liu X, Zhang H, Li W, Fu L and Ma Y: Girdin, an actin-binding protein, is critical for migration, adhesion, and invasion of human glioblastoma cells. J Neurochem 131: 457-469, 2014

28. Weng L, Han Y, Enomoto A, Kitaura Y, Nagamori S, Kanai Y, Asai N, An J, Takagishi M, Asai M, et al: Negative regulation of amino acid signaling by MAPK-regulated 4F2hc/Girdin complex. PLoS Biol 16: e2005090, 2018.
29. Garcia-Marcos M, Ear J, Farquhar MG and Ghosh P: A GDI (AGS3) and a GEF (GIV) regulate autophagy by balancing G protein activity and growth factor signals. Mol Biol Cell 22: 673-686, 2011

30. Wang S, Lei Y, Cai Z, Ye X, Li L, Luo X and Yu C: Girdin regulates the proliferation and apoptosis of pancreatic cancer cells via the PI3K/Akt signalling pathway. Oncol Rep 40: 599-608, 2018.

31. Livak JK and Schmittgen TD: Analysis of relative gene expression data using real-time quantitative PCR and the 2(-Delta Delta C(T)) method. Methods 25: 402-408, 2001

32. Wang C, Qiao C, Wang R and Zhou W: KiSS-1-mediated suppression of the invasive ability of human pancreatic carcinoma cells is not dependent on the level of KiSS-1 receptor GPR54. Mol Med Rep 13: 123-129, 2016.

33. Si W, Liu X, Wei R, Zhang Y, Zhao Y, Cui L and Hong T: MTA2-mediated inhibition of PTEN leads to pancreatic ductal adenocarcinoma carcinogenicity. Cell Death Dis 10: 206, 2019.

34. Huang J, Mei H, Tang Z, Li J, Zhang X, Lu Y, Huang F, Jin Q and Wang Z: Triple-amiRNA VEGFRs inhibition in pancreatic cancer improves the effificacy of chemotherapy through EMT regulation. J Cont Rele 245: 1-14, 2017.

35. Aiello NM, Brabletz T, Kang Y, Nieto MA, Weinberg RA and Stanger BZ: Upholding a role for EMT in pancreatic cancer metastasis. Nature 547: E7-E8, 2017.

36. Braitsch CM, Azizoglu DB, Htike Y, Barlow HR, Schnell U, Chaney CP, Carroll TJ, Stanger BZ and Cleaver O: LATS1/2 suppress $\mathrm{NF} \kappa \mathrm{B}$ and aberrant EMT initiation to permit pancreatic progenitor differentiation. PLoS Biol 17: e3000382, 2019.

37. Lekka K, Tzitzi E, Giakoustidis A, Papadopoulos V and Giakoustidis D: Contemporary management of borderline resectable pancreatic ductal adenocarcinoma. Ann Hepatobiliary Pancreat Surg 23: 97, 2019.

38. Bu JQ and Chen F: TGF- $\beta 1$ promotes cells invasion and migration by inducing epithelial mesenchymal transformation in oral squamous cell carcinoma. Eur Rev Med Pharmacol Sci 21: 2137-2144, 2017.

39. Zhang Y, Li JH, Yuan QG, Cao G and Yang WB: Upregulation of LASP2 inhibits pancreatic cancer cell migration and invasion through suppressing TGF- $\beta$-induced EMT. J Cell Biochem 120: 13651-13657, 2019.

40. Mann KM, Ying H, Juan J, Jenkins NA and Copeland NG: KRAS-related proteins in pancreatic cancer. Pharmacol Ther 168: 29-42, 2016.

41. Song M, Bode AM, Dong $\mathrm{Z}$ and Lee MH: AKT as a therapeutic target for cancer. Cancer Res 79: 1019-1031, 2019.

42. Martini M, De Santis MC, Braccini L, Gulluni F and Hirsch E: PI3K/AKT signaling pathway and cancer: An updated review. Ann Med 46: 372-383, 2014.

43. Yamamoto S, Tomita Y, Hoshida Y, Morooka T, Nagano $\mathrm{H}$, Dono K, Umeshita K, Sakon M, Ishikawa O, Ohigashi $\mathrm{H}$, et al: Prognostic significance of activated Akt expression in pancreatic ductal adenocarcinoma. Clin Cancer Res 10: 2846-2850, 2004.

44. Stoll V, Calleja V, Vassaux G, Downward J and Lemoine NR: Dominant negative inhibitors of signalling through the phosphoinositol 3-kinase pathway for gene therapy of pancreatic cancer. Gut 54: 109-116, 2005.

45. Ng SSW, Tsao MS, Chow S and Hedley DW: Inhibition of phosphatidylinositide 3-kinase enhances gemcitabine-induced apoptosis in human pancreatic cancer cells. Cancer Res 60: 5451-5455, 2000.

46. Ni W, Fang Y, Tong L, Tong Z, Yi F, Qiu J, Wang R and Tong X: Girdin regulates the migration and invasion of glioma cells via the PI3K-Akt signaling pathway. Mol Med Rep 12: 5086-5092, 2015.

47. Mittal Y, Pavlova Y, Garcia-Marcos M and Ghosh P: Src homology domain 2-containing protein-tyrosine phosphatase-1 (SHP-1) binds and dephosphorylates G(alpha)-interacting, vesicle-associated protein (GIV)/Girdin and attenuates the GIV-phosphatidylinositol 3-kinase (PI3K)-Akt signaling pathway. J Biol Chem 286: 32404-32415, 2011.

This work is licensed under a Creative Commons Attribution-NonCommercial-NoDerivatives 4.0 International (CC BY-NC-ND 4.0) License. 